\title{
E-DEMOCRACY AND ENHANCING PUBLIC ADMINISTRATION IN UKRAINE: THE ISSUES OF TRANSITION
}

\section{Kormych L. I., Kormych A. I.}

\section{INTRODUCTION}

The current Ukrainian political agenda includes a strong discourse of development of e-democracy and e-government that are viewed as one of the goals and at the same time as powerful tools of successful political and public administration reforms. However, the apparent lack of critical approach to the excising theories and practical models may influence both the efficiency of implementation and expectances of consequences of introduction of egovernment and e-democracy tools.

Hence, the overview of transformation of Ukrainian public administration on its declared pass to e-democracy includes evaluating the effectiveness of models and technologies for managing social relationships and processes, as well as analyzing the main directions and forms of their regulation. In this aspect, particular importance is given to the issues of the edemocracy and e-government correlations that characterize governance in today's information society. Besides, there is important to explore the dynamics of concepts, to look at existing models from the perspective of advantages and limitations. Quality of functioning of the management system, prompt response to changing needs, tools of prospective planning, expansion of participation in management and range of methods of communication interaction - all this is a substantial filling of the process of optimization of management mechanisms.

Concerning the overload of the issue with acts based on declarative norms the focus is made on distinguishing practical changes in the regulation environment of e-governance and e-democracy in Ukraine. The approach possesses the potential to reveal actual dynamics of political will and government intentions towards development of e-government solutions and encouraging the society's e-participation. Besides it helps to disclose obstacles and national peculiarities in the field.

\section{E-Democracy and E-Governance: Developments and Correlations}

Various definitions of e-democracy "tend to stress the potential of information and communication technologies in a broader democratic process at local, regional, national and increasingly at global levels, in which people 
interact, deliberate, make decisions and conduct elections" ${ }^{1}$. Hence, in the narrow understanding e-democracy is viewed as a mere application of ICT to a political process to facilitate, enhance and faster its different aspects.

At the same time, the broader views on e-democracy stipulate it as "the use of information and communication technologies to enhance and in some accounts replace representative democracy" ${ }^{2}$. The concept is predominantly based on the views on the Internet and social networks as the primary mediums for communicating and debating a political discourse. In latter case e-democracy is a result of combination of technological and social changes within developments of information society that not mere facilitate political process, but also change the content of political process itself.

However, there are approaches that traces the history of generic ideas of e-government back to 1950s, determining three basic stages of its development:

- 1950-1960 - "The governing machine", which was based on the computer capabilities to process big amount of data for improving public administration; thus the State was viewed as the central actor and coordinator of societies;

- 1970-1980 - "Teledemocracy" created by the cable TV networks to grant better relationships between citizen and elected officials with the emphasis on local communities as a laboratory of strong democracy;

- 1990-2000 - “Cyber-democracy" established on computers networking that provide cyberspace and virtual communities as tools for political self-organization; so that a citizen becomes an autonomous agent in global public sphere ${ }^{3}$.

In any case 1990s were the period when the contemporary understanding of e-democracy was drawn up both at the scientific and practical levels. Indeed, the online participation as a vehicle for effective, manageable dialogue between representatives and represented has been examining since $1997^{4}$.

Indicatively, the non-state actors were the ones, who started the practical transition to e-democracy. For example, the World's first election information website was created in 1994 by the civil society organization Minnesota E-Democracy. It was also held the first online candidate debate;

${ }^{1}$ Anheier H., Glasius M., Kaldor M. Global Civil Society 2004/5. London. SAGE. 2005. P. 110.

${ }^{2}$ Chadwick A. E-democracy. Encyclopedia Britannica. 2018. URL: https://www.britannica.com/topic/e-democracy.

${ }^{3}$ Vedel T. The Idea of Electronic Democracy: Origins, Visions and Questions: Origins, Visions and Questions. Parliamentary Affairs. 2006. No. 59 (2). P. 226-235. URL: https://hal.archives-ouvertes.fr/hal-01475858v2/document.

${ }^{4}$ Politics, Democracy and E-Government: Participation and Service Delivery: Participation and Service Delivery. Ed. by Christopher G. Reddick. Hershey. IGI Global. 2010. P. 169. 
and MN-Politics online forum launched creating longest lasting statewide online citizen-to-citizen discussion ${ }^{5}$.

As for the state's initiatives that fall within frameworks of e-democracy concept, the first examples include:

- developing online petitioning by Scottish Parliament in 1998 to provide a better support of electronic participation agenda of the Parliament;

- developing a secure Internet voting system, using national ID cards in 2003 in Austria to increase in voter participation among the key segments of population, including professional bodies and chambers of commerce and Austrian living abroad ${ }^{6}$.

What was important, both types of actors, non-State and State ones, were primary focused on the increasing participation of citizens by giving the latter specific ICT tools to communicate and to act within general current of political process. The main difference however is influence of those tools upon results of political process. The tools provided by non-State actors have indirect effect upon results of political process; i.e. a citizen has to transfer their online participation in voting by themselves. At the same time State-provided tools have a potential of direct effect through signing an online petition or voting online. This, actually, does not manifest that State actors do not extensively use indirect tools, but the number of authors point that the chronology of such usage is reversed. While blogs and social networking tools are relatively new innovations in political realm, other ITC tools have been around much longer: discussion forums, e-consultations, epetitions and the like ${ }^{7}$.

It is notable, that e-democracy tools are most effective in cases where State actors are included into respective communications. The issue is basically represented within theoretical discussions on the correlation between e-democracy and e-government. Furthermore, both categories are widely used together in a great number of various governmental programs related to introduction of ICT in public administration.

In aggregate all outlooks are based on recognizing of crucial role of e-governance and its tools, procedures and technologies for development and functioning of e-democracy. A weaker version of this outlook sees a tight link between e-governance and e-democracy, that is, that the two are compatible (the complementary model). A somewhat stronger version sees

${ }^{5}$ Clift S. History of E-Democracy. E-Democracy.org - Project Blog. 2015. URL: http://blog.e-democracy.org/posts/2647. 2005. P. 110.

Anheier H., Glasius M., Kaldor M. Global Civil Society 2004/5. London. SAGE.

${ }^{7}$ Politics, Democracy and E-Government: Participation and Service Delivery: Participation and Service Delivery. Ed. by Christopher G. Reddick. Hershey. IGI Global. 2010. P. 169. 
e-governance as a preliminary step, leading toward e-democracy (the evolutionary model $)^{8}$.

The rather comprehensive approach to the issue has been established in the Report of Committee on Constitutional Affairs of European Parliament on e-democracy in the European Union: potential and challenges. In particular, this Report reviewed thee concepts, that was determined as ones had principal distinguishes, but in the same time obviously overlapped:

- E-Government: refers to the use of ICT in the workings of the public sector, particularly to provide individuals with information and services from public authorities electronically (for example, payment of a speeding ticket).

- E-Governance: refers to the use of ICT to establish communication channels that enable the inclusion of the various stakeholders with something to say about the policy-making process (for example, through electronic public consultations on whether a particular speed limit should be changed, or local budget consultations).

- E-Democracy: refers to the use of ICT to create channels for public consultation and participation (for example, an e-parliament, e-initiatives, evoting, e-petitions, e-consultations $)^{9}$.

In this example different concepts constitute a kind of hierarchy with respect to the level of inclusion of private actors into relations with public administration, where the lowest level is e-government - obtaining services; the medium level is represented by e-governance - inclusion in policymaking; and the highest one - e-democracy that provides participation in policy-making.

By using the ideas of overlapping and hierarchy between concepts in question it is possible to define an e-democracy as an enhanced model of e-government, which provides two-way political communication and participation of non-state actors in decision-making process. The ultimate stage of e-governance, then, combines efficiency with democracy, allowing cheaper, more efficient channels of transactions between government and citizens/businesses, and enhancing democratic participation ${ }^{10}$.

However, the above-mentioned definitions provide timid distinctions between e-governance and e-democracy, so fare it is difficult to draw a clear line between inclusion and participation in policy making i.e. in cases

${ }^{8}$ Fisher E. E-Governance and E-Democracy: Questioning technology-centered categories. The Oxford Handbook of Governance. Ed. By David Levi-Faur. New York. Oxford University Press. 2012. P. 570-571.

${ }^{9}$ Report on e-democracy in the European Union: potential and challenges (2016/2008(INI)). European Parliament. Committee on Constitutional Affairs. 16.2.2017. A80041/2017. URL: http://www.europarl.europa.eu/doceo/document/A-8-2017-0041_EN.html.

${ }^{10}$ Fisher E. E-Governance and E-Democracy: Questioning technology-centered categories. The Oxford Handbook of Governance. Ed. By David Levi-Faur. New York. Oxford University Press. 2012. P. 572. 
of petitions or consultations. Furthermore, in some cases such tools of e-democracy like public hearings or referenda may not bear decisive importance for policy making not exceeding the consulting role.

In fact, the best possible distinction between e-governance and edemocracy may be provided through defining the main stakeholder of transformations brought by the application of ITC. The example of such differentiation may be voting technology. "To the extent that improved voting technology reduces government's cost of conducting a reliable vote, it is egovernment. But to the extent it systematically influences who votes, whose votes are actually counted or any other variable that affects the translation of voter preferences into public policy, it is e-democracy"11. Thus, so far digitalization of public administration influences its own workflow, it remains the mere issue of e-government. But from the point where transformations invariably include the ways and means of civil control of administration this is instantly becoming the ample scope of e-democracy.

\section{E-government functionality as the cornerstone of e-democracy: advantages and limitations}

Every particular State urging the development of e-government faces a need to proceed through the certain sequence of steps, that primary include the implementation of ICT, providing respective legal frameworks and implementing new ICT-based administrative procedures. Eventually, such process is built upon the principles of transaction from less comprehensive to more enhanced models of e-government to be introduced. A number of models exist next to each other, but all agree that the... steps consist of:

(1) presence of government or governmental institutions on the web,

(2) followed by the possibility of transactions with government by citizens and businesses;

(3) whereas the third (and further) step(s) involve(s) interactive government $^{12}$.

Basically, when the e-government development reaches the abovementioned third and extra steps, it is possible to speak of the introduction of e-democracy features into political process and public administration workflow. Grounding on the fact that e-government is closely related to democracy and social inclusion... the following framework can be depicted, which emphasizes the four major dimensions of e-government:

- service provision;

${ }^{11}$ Snider J.H. E-Government vs. E-Democracy. Government Technology. August 2, 2001. URL: https://www.govtech.com/magazines/gt/E-Government-vs-E-Democracy.html.

${ }^{12}$ Kampen J., Snijkers K. E-Democracy. A Critical Evaluation of the Ultimate E-Dream. Social Science Computer Review. 2003. Vol. 21 No. 4. Winter pp. 491-496. DOI: 10.1177/ 0894439303256095. 
- government performance;

- democracy (political side of e-government);

- and the social contribution of technology ${ }^{13}$.

The compaction of above-mentioned e-government "dimensions" with the fundamental features of e-democracy may highlight interconnections between the development e-government tools and creation proper conditions for growing of e-democracy. The key distinguish here is the extension of edemocracy's functions and tools to the communications within civil society between solely private actors. In brief basic features of e-democracy may be presented in this way (Table 1):

Table 1

What is E-democracy? After Simic D. Necessary steps for implementation of e-Democracy solutions ${ }^{14}$

\begin{tabular}{|l|l|}
\hline \multicolumn{2}{|c|}{ What is E-Democracy? } \\
\hline \multicolumn{1}{|c|}{$\begin{array}{c}\text { Use of ICTs for communication } \\
\text { between Government and the citizen }\end{array}$} & \multicolumn{1}{c|}{$\begin{array}{c}\text { Citizens providing online } \\
\text { support to each other }\end{array}$} \\
\hline $\begin{array}{l}\text { • Information provision } \\
\text { (eTransparency - web sites) }\end{array}$ & $\begin{array}{l}\text { - Web 2.0 services like - online } \\
\text { discussion groups, chat-rooms, wikis, } \\
\text { blogs, etc. }\end{array}$ \\
\hline $\begin{array}{l}\text { - Public consultation (eParticipation - } \\
\text { on-line polling, discussions, fora, } \\
\text { petitions, Web 2.0 etc.) }\end{array}$ & \\
\hline $\begin{array}{l}\text { - Decision-making and elections } \\
\text { (eVoting) }\end{array}$ & \\
\hline - Providing services (eGovernment) & \\
\hline
\end{tabular}

At this point the major differences in a State's strategies for development e-government and e-democracy become prominent. Steps toward e-government are primary based upon certain positive obligations of public administration (i.e. to provide administrative services online). But the transition to e-democracy requires States also to follow variety of important negative obligations (i.e. respect to freedom of speech online or online privacy, limitation of controls over provision of online-services by private actors, etc.).

Also, it was widely discussed that in many cases elected politicians might be rather anxious about implementing tools that have potential to dramatically increase civil control over public administration and to change

${ }^{13}$ Abu-Shahab E. E-democracy: The fruit of e-government. International Journal of Technology and Globalization. January 2015. DOI: 10.1504/IJTG.2015.077873.

${ }^{14}$ Simic D. Necessary steps for implementation of e-democracy solutions. E-Democracy. ICT-A Driver for Improving Democracy. Ohrid. 2010. URL: https:/bib.irb.hr/datoteka/ 579044.2010-09-12_Ohrid_Diana_Simic_e-Democracy2010.pdf. 
traditional current of political process. When encouraging of e-government is a win-win strategy due to popularity of improving services and cutting expenses, encouraging e-democracy with its easily accessible public records may increase risks of not-reelection because political opponents may exploit such records ${ }^{15}$.

Besides, the very important for many States is the recognized potential of e-Governance to counteract corruption in a public administration. Inherently, this potential may be viewed as a side effect of general increase of transparency and remoteness of online interactions between citizens and officials provided by the e-government tools. In particular, the counteracting corruption within the e-government ITC instruments can be explained in four principal ways.

1) Increasing the volume of opened information - e-government provides the opportunity to prevent abuse of power and corruption in addition to satisfying people's right to know and improving trust between government and citizens.

2) Control of discretionary work - e-government reduces the possibility of public officials to interpret laws through free discretion by attracting the attention of information disclosure and public scrutiny.

3) Reduction of face-to-face opportunities - therefore, the possibility of unfair treatment by public officials and citizens through direct meeting, that is to say, the possibility of corruption, can be reduced.

4) Expansion of competition - e-government technologically implements an environment in which all private operators can participate in open competition in government procurement contracts ${ }^{16}$.

The anticorruption component of e-governance provides the entire concept with additional attraction for post-Soviet States and developing countries, where corruption causes much more financial loss than redundant and unnecessary paperwork or difficulties in communications and obtaining information.

However, recent empirical researches frequently enough are questioning such theoretical ICT anticorruption concepts at least in terms of self-sufficiency of an ICT implementation to counteract corruption in public administration. For example, the study of the relationship between E-government and corruption using global panel data from 176 countries covering the period from 2003 to 2014 demonstrate that E-government is less

${ }^{15}$ Snider J.H. E-Government vs. E-Democracy. Government Technology. August 2, 2001. URL: https://www.govtech.com/magazines/gt/E-Government-vs-E-Democracy.html.

${ }^{16}$ Lee E. The Impact of E-government on Corruption Control. Martin School of Public Policy \& Administration. Lexington, 2017. p. 10 - 12. URL: https://www.martin.uky.edu/sites/ martin.uky.edu/files/Capstone_Projects/Capstones_2017/Lee.pdf. 
significant for reducing corruption compared to the positive impact of a country's government effectiveness, political stability and economic status ${ }^{17}$.

This particularly erects the question for what extent are e-government and e-democracy independent from national peculiarities of the "conventional" public administration and democracy? Or, maybe, they should be viewed as a kind of superstructure over existing national governmental and political substructure, which not mere enhances the effectiveness of latter, but also absorbs all existing peculiarities and fundamental flaws.

Finally, it may be fruitful to recall a criticism that is addressed to a practical realization of e-democracy initiatives. Such criticism in aggregate can be sort out to three basic points:

- a very demanding conception of citizenship that presumes a "good citizen”, which is hyperactive in cyberspace;

- a democracy reduced to discussion, while decision-making processes are disregarded;

- an abolishment of intermediary bodies (i.e. political parties and largescale media) in public affairs ${ }^{18}$.

These concerns naturally draw certain limitations to the efficiency of full-scale application of major tools of e-governance and e-democracy without keeping strong back-ups in forms of conventional procedures and institutions. Furthermore it shows the importance of reaching the proper levels of "e-readiness" for a State and society.

\section{The Development of E-Government Legal Framework in Ukraine: Wandering to e-Democracy}

Concerning the development of e-government as a sequence of steps from a basic to an enhanced model, it is usually emphasized that there are no legal pre-requisites for starting the process of introduction of e-governance. Eventually, for starting a simple web-presence of public administration bodies the question is rather lies in a plain of a proper infrastructure and ITC availability. When every further step requests specific regulations, starting from recognition of electronic transactions equally to paper ones and up to limit some functions of public administrations to be done exclusively in electronic forms.

To that end major of recommended standards and good practices in the field distinguish three levels of e-governance legal framework:

${ }^{17}$ Basyal, D., Poudyal, N. and Seo, J. Does E-government reduce corruption? Evidence from a heterogeneous panel data model. Transforming Government: People, Process and Policy. 2018. Vol. 12. No. 2, pp. 134-154. https://doi.org/10.1108/TG-12-2017-0073.

${ }^{18}$ Vedel T. The Idea of Electronic Democracy: Origins, Visions and Questions: Origins, Visions and Questions. Parliamentary Affairs. 2006. No. 59(2). Pp. 226-235. URL: https://hal.archives-ouvertes.fr/hal-01475858v2/document. 
- Basic level, that is associated rather with elimination obstacles to the implementation of e-governance (any legislation incompatible with egovernance is mapped; analysis of the legal system is conducted);

- Useful level, which provides regulations for key features of egovernance and e-readiness in general (a minimum level of legislation of relevance for e- governance is adopted; specific regulation for data protection, electronic identity and signature, civil registers and for protection of national cyberspace is adopted);

- Sustainable level, when e-governance becomes en essential element of public administration and in some cases for trans-border cooperation (all legal acts are consistent with details of e-governance; legal environment at regional level is harmonized) ${ }^{19}$.

Pretty vivid characteristics of Ukrainian developments in the field of egovernance are UN global rankings in provided in UN E-Government Surveys. Such rankings were based on two different indexes: the UN E-Government Readiness Index for the period of 2003 - 2008 and UN E-government Development Index (EGDI) for 2010 - 2018, however, the rankings itself are useful for illustration of dynamics of respective processes (Table 2, 3).

Table 2

Ukraine's ranking in UN E-Government Readiness Index based on UN E-Government Surveys $2003^{20}-2008^{21}$

\begin{tabular}{|c|c|c|c|}
\hline \multicolumn{4}{|c|}{ Ukraine in UN E-Government Readiness Index } \\
\hline Year & Rank & Index & Average Europe \\
\hline 2003 & 54 & 0.462 & 0.558 \\
\hline 2005 & 48 & 0.5456 & 0.5556 \\
\hline 2008 & 41 & 0.5728 & 0.5689 \\
\hline
\end{tabular}

The figures above show, in particular, a comparative lack of sustainability of development of e-government and what is important - of its online services components. One can accurately identify the distinct peaks of ranking in 2008 and 2016 that were instantly followed by the noticeable regressing in 2010-2014 and 2018.

${ }^{19}$ Guidelines and Roadmap for full deployment of e-governance systems in Africa. Final Report. January 2019. European Commission. DG for International Cooperation and Development. 2019. P. 48. (148) URL: https://ega.ee/wp-content/uploads/2019/04/eGA_FinalReport-Research-analysis-guidelines-and-roadmap-for-full-deployment-of-e-governance-systemsin-Af.pdf.

${ }^{20}$ UN Global E-Government Survey 2003. New York, UN. 2004. https://doi.org/ 10.18356/f8a93d8f-en.

${ }^{21}$ United Nations E-Government Survey 2008: From E-Government to Connected Governance. New York. UN. 2008. https://doi.org/10.18356/047afd3a-en. 
Table 3

Ukraine's ranking in UN EGDI based on UN E-Government Surveys of $2010^{22}, \mathbf{2 0 1 2}^{23}, \mathbf{2 0 1 4}^{24}, \mathbf{2 0 1 6}^{25}$ and $2018^{26}$

\begin{tabular}{|c|c|c|c|c|c|c|}
\hline \multicolumn{7}{|c|}{ Ukraine in UN E-government Development Index } \\
\hline Year & Rank & EGDI & $\begin{array}{c}\text { Online } \\
\text { Service } \\
\text { Component }\end{array}$ & $\begin{array}{c}\text { Telecom. } \\
\text { Infrastructure } \\
\text { Component }\end{array}$ & $\begin{array}{c}\text { Human } \\
\text { Capital } \\
\text { Component }\end{array}$ & $\begin{array}{c}\text { Average } \\
\text { Europe } \\
\text { EGDI }\end{array}$ \\
\hline 2010 & 54 & 0.5181 & 0.1117 & 0.0821 & 0.3184 & 0.6227 \\
\hline 2012 & 68 & 0.5653 & 0.4248 & 0.3535 & 0.9176 & 0.7188 \\
\hline 2014 & 87 & 0.5032 & 0.2677 & 0.3802 & 0.8616 & 0.6936 \\
\hline 2016 & 62 & 0.6076 & 0.5870 & 0.3968 & 0.8390 & 0.7241 \\
\hline 2018 & 82 & 0.6165 & 0.5694 & 0.4364 & 0.8436 & 0.7727 \\
\hline
\end{tabular}

In addition, this reveals the apparent inconsistency of the State policy in the field whereas proper programs and ambitious plans rather often appear too declarative.

Besides, the above mentioned rankings for a noticeable extend reflect the dynamics of the political will on introduction of e-government solutions into public administration routine and therefore the same dynamics of administration's readiness for transformations required for transition from simple application of ICT to implementing certain e-democracy features.

It should be also noted, that accelerations in e-government developments in Ukraine perfectly correlate with the periods just after enormous political protests - "The Orange Revolution” (winter of 2003-2004) and "The Revolution of Dignity" (winter of 2013-2014) that have revealed demands of society for the democratic transformations, transparency and service orientation of public administration, counteracting corruption, etc. And the e-government tools have been always viewed as one of the proper solution for these objectives. Thus the governments that came to power after that political protests were deeply concerned with e-transformations, at least at the beginning.

Eventually, on the grounds of the above mentioned rankings we suggest classifying two distinct periods in development of e-governmental

${ }^{22}$ United Nations E-Government Survey 2010: Leveraging E-Government at a Time of Financial and Economic Crisis. New York. UN. 2010. https://doi.org/10.18356/0e749d15-en.

${ }^{23}$ United Nations E-Government Survey 2012: E-Government for the People, New York. UN. 2012. https://doi.org/10.18356/b1052762-en.

${ }^{24}$ United Nations e-government survey 2014: E-Government for the future we want. New York. UN. 2014. https://doi.org/10.18356/73688f37-en.

${ }^{25}$ United Nations E-Government Survey 2016: E-Government in Support of Sustainable Development. New York. UN. 2017. https://doi.org/10.18356/d719b252-en.

${ }^{26}$ United Nations E-Government Survey 2018: Gearing E-Government to Support Transformation Towards Sustainable and Resilient Societies. New York. UN. 2018. https://doi.org/10.18356/d54b9179-en. 
legal framework in Ukrainian legislation, which basically reflects the State policy towards role and place of e-government services in Ukrainian public administration and political process.

The first period of development of Ukrainian e-government legislation should be dated from the beginning of 2000s up to 2014. It was stated with the Order of the President of Ukraine On Additional Measures to Ensure Transparency in the Activity of Government Bodies" (2002) ${ }^{27}$, which was followed by Regulations of Cabinet if Ministers of Ukraine "On Procedure for Publishing Information about the Executive Bodies' Activity on the Internet" $(2002)^{28}$ and "On Measures for Creation of Electronic Government Information System" (2003) ${ }^{29}$. These acts obligated State and local authorities to have own web sites and to systematically publish prescribed set of information including laws and regulations. Besides all governmental web sites was integrated under single web portal. In the same period Ukrainian parliament passed the laws on electronic documents and electronic signature that was supplemented by the secondary governmental legislation.

The ambitions to develop an enhanced e-government system were also reflected in the Law of Ukraine "On the Basic Principles for the Development of an Information-Oriented Society in Ukraine for 2007-2015” (2007) ${ }^{30}$. That act included, in particular, provisions on the development of electronic services of state and local authorities and the "single point of contact" to access public administration, etc.

From the practical point of view the great importance had two Directives of Cabinet of Ministers "Issues of Implementation of the Pilot Project for Adoption of Electronic Governance”No. 360-r. (2010) and "On Approving the Concept of Development of e-governance in Ukraine" No. 2250-r. (2010). Those Directives basically launched the full-scale development of paperless workflow, electronic systems and electronic registers of public administration bodies.

The main feature of the period discussed was the focus on building up intra-administration solutions and processes, whereas citizen-oriented e-government tools were given much less attention. The major part of services

27 Указ Президента України «Про додаткові заходи щодо забезпечення відкритості у діяльності органів державної влади» від 1 серпня 2002 р. № 683/2002. Офіційний вісник України. 2002. № 31. Ст. 1463.

${ }^{28}$ Постанова Кабінету Міністрів України "Про Порядок оприлюднення у мережі Інтернет інформації про діяльність органів виконавчої влади” від 4 січня 2002 р. № 3. Офіційний вісник України. 2002. № 2. Ст. 57.

${ }^{29}$ Постанова Кабінету Міністрів України «Про заходи щодо створення електронної інформаційної системи «Електронний уряд» від 24 лютого 2003 р. № 208. Офіційний вісник України. 2003. №. 9. Ст. 378.

30 Закон України «Про Основні засади розвитку інформаційного суспільства в Україні на 2007-2015 роки» від 9 січня 2007 р. № 537-V. Офіційний вісник України. 2007. № 8. Ст. 273. 
provided were basically concerned an authorities efficiency or certain fields that were sensitive to international cooperation.

For example, the most advanced e-government solutions had been adopted in customs service even earlier, than the national-wide e-government programs were announced. The first fully operable intra-agency electronic information system had been created by Ukrainian customs service in 1996, which was followed by launching a trial electronic declaration in $2004^{31}$. However, for that period very tiny share of citizens contacted customs (only $1,9 \%$ due to surveys of 2011) and did not provide any significant reduction of corruption (36,1\% have faced the requesting of bribes) ${ }^{32}$.

Overall, the introduction of e-government solutions in a period of 2000 - 2014 with respect to providing general conditions for e-democracy had been on a low track. Researches made in 2015 by the eGovernance for Accountability and Participation (EGAP) Program showed pretty concise results both in terms of usage of e-Democracy services, and in terms of evaluation of the influence of implementation of ITC upon communications between public administration and citizens. For example, due to the national public opinion surveys conducted in Ukraine in February and December 2015 the citizens' usage of e-Democracy features included:

- Seek general government information - 24\%;

- Respond to online polls - 9\%;

- Interact with civic organizations online $-6 \%$;

- Communicate directly with local authorities $-5 \%$;

- Access eServices - 4\%;

- File complaints $-4 \%^{33}$.

It was rather pronounced that major but at the same time pretty low share of communications within e-Democracy frameworks did not went above simple Internet queries. Contrary, the usages of features that provide electronic “access to the State” in aggregate shared only $11 \%$ of respondents' answers.

As for influence of ICT upon different aspects of communication between government and citizens the respective surveys showed remarkably greater "e-democracy skepticism among respondents that qualified themselves as "non-users of Internet". Thus, affirmative answer was given about influence of ICT on:

${ }^{31}$ E-Governance in Ukraine: Effective Governance for Citizens. Kyiv. UNDP/MGSDP. 2011. 56 p. URL: https://www.undp.org/content/dam/ukraine/docs/JK/e-governance_publication_ en.pdf.

${ }^{32}$ Corruption in Ukraine. Comparative Analysis Of National Surveys: 2007, 2009, 2011, and 2015. Kiev International Institute of Sociology. 2015. URL: https://kiis.com.ua/materials/pr/ 20161602_corruption/Corruption\%20in\%20Ukraine\%202015\%20ENG.pdf.

${ }^{33}$ eDemocracy in Ukraine: Citizens' \& Key Stakeholders' Perspectives. Kyiv. EGAP Program. 2016. p. 5. URL: http://egap.in.ua/wp-content/uploads/2016/01/07.07.pdf. 
- Improving government-citizen communication and accountability 76\% (Internet Users) and 37\% (Non-Users);

- Increase transparency and citizens' trust in public authorities - 44\% and $19 \%$;

- Better informed citizens about government - 35\% and 15\%;

- Increase effectives of eServices - $29 \%$ and $13 \%$, respectively ${ }^{34}$.

The second period, which started after 2014, has had a distinct emphasis on digital transformations and usage of e-government applications as the backbone of public administration reforms. From the very beginning the policy-making towards e-governance was integrated by Ukrainian State Agency for eGovernance, launched in 2014 (in 2019 that body was reorganized into Ministry of Digital Transformation of Ukraine).

In 2015 Ukrainian parliament issued an important act eliminating obstacles for government transparency and reuse of public information. The Law of Ukraine "On Amendments to Some Laws of Ukraine on Access to Public Information in The Form of Open Data” $(2015)^{35}$ created frameworks for creation of "The Single web-portal of Open Data” (https://data.gov.ua), which for a moment have integrated 24,533 databases of state and local authorities.

The most important motion to counteract corruption thought application of e-government tools was made in the field of state procurement. The Law on Public Procurement (2016) ${ }^{36}$ provided that the contracting authority shall carry out the procurement procedures through the use of an electronic procurement system (Art 12:2) and the electronic procurement system itself must be accessible to the public and guarantee nondiscrimination (Art 12:3). Hence, the procedure of government procurements was completely and obligatory transferred on-line and provided full transparency of tenders held and contracts concluded.

The respective system of electronic public procurement named ProZorro is comprised of the portal database and the module of electronic auction. Besides, the ProZorro system has been extended with Prozorro Sale, which is a system designed for the transparent, fast and effective sales of state and communal property, as well as fighting against corruption through equal access to data, public control and increasing the number of the potential buyers ${ }^{37}$.

${ }^{34}$ eDemocracy in Ukraine: Citizens' \& Key Stakeholders' Perspectives. Kyiv. EGAP Program. 2016. p. 5. URL: http://egap.in.ua/wp-content/uploads/2016/01/07.07.pdf.

35 Закон України «Про внесення змін до деяких законів України щодо доступу до публічної інформації у формі відкритих даних» від 9 квітня 2015 р. № 319-VIII. Офіційний вісник України. 2015. № 35. Ст. 1033.

${ }^{36}$ Закон України «Про публічні закупівлі» 25 грудня 2015 р. № 922-VIII. Офіційний вісник України. 2016. № 15. Ст. 582.

${ }^{37}$ Digital Government Factsheet 2019: Ukraine. European Commission. 2019. URL: https://www.ospi.es/export/sites/ospi/documents/documentos/Administracion-Digital/Digital_ Government_Factsheets_Ukraine_2019.pdf. 
The e-services segment was provided with the new Law of Ukraine On Trust Electronic Services (2017) $)^{38}$ and amended Law of Ukraine "On Administrative Services", that was also supplemented by relevant secondary legislation. Information of administrative services available online is integrated though the Single State Portal of Administrative Services (https://my.gov.ua ). At the end of 2018 about 119 e-services were available to citizens and businesses and also more than 50 were planned for moving online in 2019. The most popular services already accessible online include such categories, as:

- welfare services (e-Maliatko - childbirth registration, utility subsidies, services of the Pension Fund of Ukraine);

- services for businesses (business registration, issuance of licenses and authorizations, receipt of extracts and certificates online);

- construction-related services (start and commission of construction projects);

- services related to security and courts (certificates on lack of criminal conviction, lack of corruption offenses, file a sue with a court online);

- Driver's E-Cabinet (information online of a vehicle, driver's license, fines, register online for service centers);

- Carrier's E-Cabinet (obtaining or revoking passenger and freight transportation licenses, lodging companies' details) ${ }^{39}$.

The important segment of current e-government legislation is providing the rule that individual data elements should only be submitted to authorities just once, which demands operable data exchange between different state agencies, local authorities and other relevant bodies. To this end in 2018 the "Trembita" system was launched, which was defined as "the system of electronic interaction of state electronic information resources and also the system of interoperability in Ukraine". "Trembita" operates in accordance with the provisions of Regulation of Cabinet of Ministers of Ukraine "Some issues of electronic interaction of state electronic information resources" $(2016)^{40}$. The system is based on the Estonian X-ROAD data exchange platform, created by Estonian government as its own e-governance solution and integrates 20 state registers including confidential information that are used by authorities to provide administrative services and other powers.

The most recent development in the field of e-governance is the project "Diia” (Action), which is supported by the same named state enterprise.

${ }^{38}$ Закон України «Про електронні довірчі послуги» від 5 жовтня 2017 р. № 2155-VIII. Офіційний вісник України. 2017. № 91. Ст. 2764.

${ }^{39}$ E-Services Development. Government Portal. ULR: https://www.kmu.gov.ua/en/ reformi/efektivne-vryaduvannya/rozvitok-elektronnih-poslug.

${ }^{40}$ Постанова Кабінету Міністрів «Деякі питання електронної взаємодії державних електронних інформаційних ресурсів» від 8 вересня 2016 р. № 606. Офіційний вісник України. 2016. № 73. Ст. 2455. 
"Diia" is the planned online portal of public services, the online portal of public services and dedicated smartphone application that goes through testing now (so far it only provides using a virtual driver's license and vehicle registration documents in smartphone) ${ }^{41}$.

\section{CONCLUSIONS}

Enhancing of public administration capabilities through application of ICT is a crucial factor of e-democracy development. The sustainability of e-government development is one of key factors for any State to stay on track of fast changes of ITC applications, e-services and e-procedures. On top of that the very important factors are overall level of public administration and society's involvement, since the e-government tools so far have not proved their self-sufficiency for providing positive transformations in a state administration and political process.

Summarizing the review of main segments of Ukrainian e-governance development in period "after 2014" it is possible to define strong vectors of state policy in the field towards increasing transparency and service oriented workflow of State and local authorities and counteracting corrupttion through conducting most corruption sensitive procedures solely in electronic form with very high level of openness to public. This combination of e-governance functions affirmatively moves the whole process close to introduction of e-democracy.

However, it is possible to detect a number of flaws that prevents fullscale transformations both of the public administration and the society's participation. General overlook shows two major aspect of the issue.

The first aspect is the discussed in paper threat of reducing e-democracy to discussion without real influence upon decision-making. For example, even the most successful Ukrainian e-government project ProZorro have certain issues with conversion of transparency into real actions against possible signs of corruption detected. Owing to high level of transparency of procurement through ProZorro, the community was enabled to detect the procurement procedures that may entail violation of law, as provided for by Article 9 of the Law of Ukraine "On Public Procurement" that concerns civic oversight. However, the e-procurement system currently does not enable notifying the controlling and law enforcement agencies on such cases. It also lacks consolidated information on how controlling and law enforcement agencies respond to the respective requests by the community ${ }^{42}$.

The second aspect is that the current Ukrainian e-governance system is rather consumer-oriented than citizens-oriented in terms of New Public

${ }^{41}$ Diia. Online Public Services. URL: https://plan.diia.gov.ua/en.

${ }^{42}$ Transparency in Public Procurement (Prozorro) (UA0073). Open Government Parnership. URL: https://www.opengovpartnership.org/members/ukraine/commitments/UA0073/. 
Service concept, that demands "that administrators should see citizens as citizens (rather than merely as voters, clients, or customers)" ${ }^{43}$. However, the current system lacks platforms for citizens, for example, to realize their rights for administrative appeal of public administrative decisions or to have really effective system of e-petitions. On top of that the new services are pretty often reported for not-sufficient level of privacy and personal data protection, which is the issue that tends to scale with further development of services if not paid proper attention.

\section{SUMMARY}

An E-democracy is an enhanced model of e-government, which provides two-way political communication and participation of non-state actors in decision-making process. The best possible distinction between e-governance and e-democracy may be provided through defining the main stakeholder of transformations. If digitalization influences public administration it remains the issue of e-government, when transformations include the civil control of administration this becoming the scope of e-democracy. There are certain limitations to the efficiency of full-scale application of major tools of e-governance and e-democracy without reaching the proper levels of "e-readiness" for a State and society. We suggest classifying two distinct periods in development of e-governmental legal framework in Ukrainian legislation. The main feature of the period was the focus on building up intra-administration solutions and processes, whereas citizen-oriented e-government tools were given much less attention. The second period, which started after 2014, has had a distinct emphasis on digital transformations and usage of e-government applications as the backbone of public administration reforms.

\section{REFERENCES}

1. Abu-Shahab E. E-democracy: The fruit of e-government. International Journal of Technology and Globalization. January 2015. DOI: 10.1504/IJTG.2015.077873.

2. Anheier H., Glasius M., Kaldor M. Global Civil Society 2004/5. London. SAGE. 2005. 375 p.

3. Basyal D., Poudyal N. and Seo J. Does E-government reduce corruption? Evidence from a heterogeneous panel data model. Transforming Government: People, Process and Policy. 2018. Vol. 12. No. 2. Pp. 134-154. https://doi.org/10.1108/TG-12-2017-0073.

4. Chadwick A. E-democracy. Encyclopedia Britannica. 2018. URL: https://www.britannica.com/topic/e-democracy.

${ }^{43}$ Denhardt R., Denhardt J. The New Public Service: Serving Rather Than Steering. Public Administration Review. 2000. Vol. 60. No. 6. Pp. 549-559. 
5. Clift S. History of E-Democracy. E-Democracy.org - Project Blog. 2015. URL: http://blog.e-democracy.org/posts/2647.

6. Corruption in Ukraine. Comparative Analysis Of National Surveys: 2007, 2009, 2011, and 2015. Kiev International Institute of Sociology. 2015. URL: $\quad$ https://kiis.com.ua/materials/pr/20161602_corruption/Corruption\% 20in\%20Ukraine\%202015\%20ENG.pdf.

7. Denhardt R., Denhardt J. The New Public Service: Serving Rather Than Steering. Public Administration Review. 2000. Vol. 60. No. 6. Pp. 549-559.

8. Digital Government Factsheet 2019: Ukraine. European Commission. 2019. URL: https://www.ospi.es/export/sites/ospi/documents/ documentos/Administracion-Digital/Digital_Government_Factsheets_ Ukraine_2019.pdf.

9. Diia. Online Public Services. URL: https://plan.diia.gov.ua/en.

10. eDemocracy in Ukraine: Citizens' \& Key Stakeholders' Perspectives. Kyiv. EGAP Program. 2016. p. 5. URL: http://egap.in.ua/wpcontent/uploads/2016/01/07.07.pdf.

11. E-Governance in Ukraine: Effective Governance for Citizens. Kyiv. UNDP/MGSDP. 2011. 56 p. URL: https://www.undp.org/content/dam/ ukraine/docs/ЛК/e-governance_publication_en.pdf.

12. E-Services Development. Government Portal. ULR: https://www.kmu.gov.ua/en/reformi/efektivne-vryaduvannya/rozvitokelektronnih-poslug.

13. Fisher E. E-Governance and E-Democracy: Questioning technology-centered categories. The Oxford Handbook of Governance. Ed. By David Levi-Faur. New York. Oxford University Press. 2012. 828 p.

14. Guidelines and Roadmap for full deployment of e-governance systems in Africa. Final Report. January 2019. European Commission. DG for International Cooperation and Development. 2019. P. 48. (148). URL: https://ega.ee/wp-content/uploads/2019/04/eGA_Final-Report-Researchanalysis-guidelines-and-roadmap-for-full-deployment-of-e-governancesystems-in-Af.pdf.

15. Kampen J., Snijkers K. E-Democracy. A Critical Evaluation of the Ultimate E-Dream. Social Science Computer Review. 2003. Vol. 21. No. 4. Winter pp. 491-496. DOI: 10.1177/0894439303256095.

16. Lee E. The Impact of E-government on Corruption Control. Martin School of Public Policy \& Administration. Lexington, 2017. 32 p. URL: https://www.martin.uky.edu/sites/martin.uky.edu/files/Capstone_Projects/ Capstones_2017/Lee.pdf

17. Politics, Democracy and E-Government: Participation and Service Delivery: Participation and Service Delivery. Ed. by Christopher G. Reddick. Hershey. IGI Global. 2010. 514 p. 
18. Report on e-democracy in the European Union: potential and challenges (2016/2008(INI)). European Parliament. Committee on Constitutional Affairs. 16.2.2017. A8-0041/2017. URL: http://www.europarl.europa.eu/ doceo/document/A-8-2017-0041_EN.html.

19. Simic D. Necessary steps for implementation of e-democracy solutions. E-Democracy. ICT- A Driver for Improving Democracy. Ohrid. 2010. URL: https://bib.irb.hr/datoteka/579044.2010-09-12_Ohrid_Diana_ Simic_e-Democracy_2010.pdf.

20. Snider J.H. E-Government vs. E-Democracy. Government Technology. August 2, 2001. URL: https://www.govtech.com/magazines/gt/ E-Government-vs-E-Democracy.html.

21. Transparency in Public Procurement (Prozorro) (UA0073). Open Government Parnership. URL: https://www.opengovpartnership.org/ members/ukraine/commitments/UA0073/.

22. UN Global E-Government Survey 2003. New York, UN. 2004. https://doi.org/10.18356/f8a93d8f-en.

23. United Nations E-Government Survey 2008: From E-Government to Connected Governance. New York. UN. 2008. https://doi.org/ 10.18356/047afd3a-en.

24. United Nations E-Government Survey 2010: Leveraging E-Government at a Time of Financial and Economic Crisis. New York. UN. 2010. https://doi.org/10.18356/0e749d15-en.

25. United Nations E-Government Survey 2012: E-Government for the People, New York. UN. 2012. https://doi.org/10.18356/b1052762-en.

26. United Nations e-government survey 2014: E-Government for the future we want. New York. UN. 2014. https://doi.org/10.18356/73688f37-en.

27. United Nations E-Government Survey 2016: E-Government in Support of Sustainable Development. New York. UN. 2017. https://doi.org/ 10.18356/d719b252-en.

28. United Nations E-Government Survey 2018: Gearing E-Government to Support Transformation Towards Sustainable and Resilient Societies. New York. UN. 2018. https://doi.org/10.18356/d54b9179-en.

29. Vedel T. The Idea of Electronic Democracy: Origins, Visions and Questions: Origins, Visions and Questions. Parliamentary Affairs. 2006. No. 59(2). P. 226-235. URL: https://hal.archives-ouvertes.fr/hal-01475858v2/ document.

30. Закон України «Про внесення змін до деяких законів України щодо доступу до публічної інформації у формі відкритих даних» від 9 квітня 2015 р. № 319-VIII. Офіційний вісник України. 2015. № 35. Ст. 1033.

31. Закон України «Про електронні довірчі послуги» від 5 жовтня 2017 р. № 2155-VIII. Офіційний вісник України. 2017. № 91. Ст. 2764. 
32. Закон України «Про Основні засади розвитку інформаційного суспільства в Україні на 2007-2015 роки» від 9 січня 2007 р. № 537-V. Офіційний вісник України. 2007. № 8. Ст. 273.

33. Закон України «Про публічні закупівлі» 25 грудня 2015 р. № 922-VIII. Офіційний вісник України. 2016. № 15. Ст. 582.

34. Постанова Кабінету Міністрів «Деякі питання електронної взаємодії державних електронних інформаційних ресурсів» від 8 вересня 2016 р. № 606. Офіційний вісник України. 2016. № 73. Ст. 2455.

35. Постанова Кабінету Міністрів України «Про Порядок оприлюднення у мережі Інтернет інформації про діяльність органів виконавчої влади» від 4 січня 2002 р. № 3. Офіційний вісник України. 2002. № 2. Ст. 57.

36. Постанова Кабінету Міністрів України "Про заходи щодо створення електронної інформаційної системи «Електронний уряд» від 24 лютого 2003 р. № 208. Офіційний вісник України. 2003. №. 9. Ст. 378.

37. Указ Президента України «Про додаткові заходи щодо забезпечення відкритості у діяльності органів державної влади» від 1 серпня 2002 р. № 683/2002. Офіційний вісник України. 2002. № 31. Ст. 1463.

\section{Information about the authors:} Kormych L. I., Doctor of History, Professor, Head of the Department of Political Theories, National University «Odessa Law Academy» 2, Academichna str., Odesa, 65009, Ukriane Kormych A. I.,

$\mathrm{PhD}$ in History, Associate Professor, Associate Professor at the Department of General Jurisprudence, National University «Odessa Law Academy» 2, Akademichna str., Odessa, 65009, Ukraine 